\title{
HERMENEUTYKA CZYNU ORAZ NOWY MODEL ŚWIADOMOŚCI
}

Filozofia a także i teologia stają się za naszych dni coraz bardziej antropologiczne. Człowiek spełnia dziś rolę soczewki, przez którą usiłujemy dojrzeć i zrozumieć rzeczywistość — łącznie z tą, która mieści się poza nim. Następuje dekosmologizacja filozofii zajmującej się człowie-kiem.

Książka Kardynała Karola Wojtyły, Osoba i czyn ${ }^{1}$, znajduje się w nurcie antropologicznej myśli, która szuka drogi tylko do człowieka prowadzącej. Nie oznacza to, że odrywa nas od oglądu struktur, które także konstytuują ludzką istotę nadając jej ontologiczny wymiar w tradycyjnym, arystotelesowsko-tomistycznym znaczeniu tego słowa.

Za jedną $z$ najcenniejszych zalet filozoficznego studium o osobie i czynie uważam to, że swoją zawartość poznawczą wysnuwa nie z pojęcia osoby, lecz z konkretu, jakim jest sam człowiek dany nam w doświadczeniu poprzez swój czyn. „Człowiek działa” — ten fakt daje Autorowi punkt wyjścia. Osoba-czyn stanowi dla niego całość (s. 13), powtarzającą się w każdym człowieku. Praca Kardynała Wojtyły nie jest więc jeszcze jedną więcej obróbką tego lub tamtego z dotychczas ,obowiązujących" pojęć istoty człowieka a kończącą się zawsze jakimś produktem zamkniętym w sobie i odpornym na dynamizm istnienia ludzkiego. W konsekwencji praca Autora nie zwalnia od dalszych istotnych poszukiwań w tym samym kierunku, lecz do nich zobowiązuje.

Osoba i czyn otwiera drogę, na której poznaje się z jednei sciony struktury, w jakich człowiek spełnia się jako człowiek (Autor przede wszystkim do ich ukazania ogranicza swoje zadanie), ale równocześnie pozwala wejść w ich zawartość, czyli w treść tworzącą jakość, wielkość

1 Kardynał Karol Wojtyła, Osoba i czyn, Kraków 1969. 
lub małość człowieka, pozwala wejść w jego dynamikę, która daje mu tylko dwie możliwości: autokreację albo autodestrukcję. W odsłanianej przez Autora perspektywie człowiek tych dwu możliwości jawi się jako istota ciągle sobie zadana do poznania oraz do zrealizowania. Myśl Autora mocno tkwiąc $\mathrm{w}$ theoria rzutuje daleko $\mathrm{w}$ praxis.

Jeżeli dobrze rozumiem myśl Kardynała Wojtyły, traktuje On czyn iako pewną rzeczywistość daną nam w doświadczeniu, któr ż należy „eksplikować”, czyli — wydobywać jej zawartość (s. 32). Należy tego dokonywać ,pod kątem odsłaniania rzeczywistości o s oby" (s. 32 i n.). Tak będziemy dokonywali interpreta c ji czynu (por. s. 19 i n.) stanowiącej, ,u te oretycznienie owej praxis" (s. 20) jakim jest ludzkie działanie. „Czyn jest szczególny m momentem, pisze Autor (s. 13), o gląd u - czyli doświadczenia - os oby". Doświadczenie osoby równocześnie jest jej zrozumieniem. Nie ma bowiem doświadczenia człowieka, $z$ naciskiem podkreśla Autor, bez równocześnie przenikającego je momentu intelektualnego. Interpretacja zatem osoby posiada zarówno charakter empiryczny jak i intelektualny.

$\mathrm{Na}$ wstępie zwrócę uwagę na uderzające pokrewieństwo koncepcji drogi do człowieka, zaproponowanej przez Kardynała Wojtyłe, z filozofią symbolu oraz z konstytuującą ją hermeneutyką czyli interpretacją tego ostatniego. W ścisłym znaczeniu filozofia symbolu ogranicza się do faktów językowych, niemniej wyrasta wszędzie tam, gdzie mamy do czynienia $\mathrm{z}$ jakimkolwiek tekstem znaczącym - w szerokim znaczeniu tego słowa jakikolwiek znaczący tekst można uważać za język. Tekstem może być także ludzki czyn. Osoba ludzka mieści się w czynie, dla nas jest w nim obecna: nie jest nam dana w nim bezpośrednio, lecz poprzez niego. Wskutek swojej niebezpośredniej obecności w czynie osoba konstytuuje go w swój symboliczny wyraz.

Kiedy mówię tu o symbolu, nie rozumiem tego słowa w sensie arystotelesowskim; ani kiedy Stagiryta mówi, że nazwa symbol służy na oznaczenie zdolności słowa do wyrażania stanów duszy, ani kiedy w Peri Hermeneias stwierdza, że mówić coś o czymś znaczy to coś interpretować (od tego stwierdzenia od razu przechodzi do logiki zdań opartej na jednoznaczności - dopiero zdanie bowiem mówi o rzeczy).

Nie tu miejsce na omawianie symbolu. Dla uniknięcia jednak nieporozumień powtórzę jedynie rzeczy najbardziej podstawowe, że w symbolu spotykamy się z dwoma płaszczyznami znaczeniowymi, i to właśnie czyni dany znak symbolem. Pierwsza dana nam jest wprost, bezpośrednio. Znajdujemy ją w słowniku pod odpowiednim hasłem. Jej treść wskazuje na coś, co daje się ująć w pojęcie. Na przykład plama spowodowana rozlaniem farby. Równocześnie jednak słowo to, kiedy mu się 
bliżej przyjrzeć w pewnych określonych okolicznościach, przenosi nas na drugą płaszczyznę znaczeniową. Dzieje się tak na skutek kontekstu, bardzo szeroko pojętego, w którym to słowo do nas przychodzi. Odkrywamy wówczas jego drugie ,znaczenie”, którego nie znajdziemy w słowniku nawet wtedy, kiedy podaje on przyjęte w danej kulturze symboliczne znaczenie poszczególnych wyrazów. To coś więcej, jawiące się nam na drugiej płaszczyźnie znaczeniowej słowa, nie daje się wyrazić jakimś sobie właściwym pojęciem i nazwą. Przekracza je, chociaż w nich się pojawia. Niejako bierze cudze i na nim odsłania siebie. Na przykład wspomniane już słowo ,plama” w odpowiednim kontekście i sytuacji niesie dla nas nowy „sens” prócz tego, który mieści się na jego pierwszej płaszczyźnie znaczeniowej: „plama”, jaka została na mnie po czynie, inna od plamy spowodowanej rozlaniem farby. To nie jest plama, a jednak ma coś z plamy. Między tym, co zostało we mnie po spełnieniu czynu (w tym przypadku czynu złego), a plamą istnieje analogia. Tę „,plamę" mogę nazwać upadkiem, zniszczeniem siebie itp., ale wszystkie te słowa ukazując mi to, o co chodzi, nie wyrażają tego bezpośrednio. Symbolizowana rzeczywistość jest niesamodzielna z punktu widzenia swojego wyrazu; żeby się wyrazić, musi korzystać z cudzych środków wyrazu. Dlaczego tak się dzieje, to inny problem. Wydaje się, że jej zbyt wielkie ontyczne bogactwo przerasta wszelki pojęciowy wyraz. Pojęcie bowiem jest statyczne, rzeczywistość natomiast dająca się ująć jedynie w symbol, jest dynamiczna w każdym swoim wymiarze. Określa się tym, czego jeszcze nie ma, a co jest jej zadane jako jej własne spełnienie.

Dzieje się jednak tutaj coś bardzo znamiennego. Nowy sens słowa polega na tym, że stanowi uobecnienie tego, co oznaczyliśmy terminem „ „oś więcej”. Dzięki temu może dojść do egzystencjalnego kontaktu z tak uobecnioną rzeczywistością; podmiot zbliżający się do niej poprzez symbol może się z nią spotkać ,namacalnie”.

Samo symbolizujące pojęcie - jego sens - nabiera sensu. Sens pojęcia staje się niejako usensowniony, gdyż rzeczywistość zasymbolizowana spełnia funkcje jego sensu. W symbolu mamy do czynienia niejako $z$ sensem sensu. A ponieważ sens zasymbolizowany jest dynamiczny, gdyż konstytuuje go sama uobecniona rzeczywistość, sens symbolizujący (pojęcie) sam staje się także dynamiczny, to znaczy otwarty na coś więcej, ku czemu ciągle trzeba dochodzić. Wszystko ma o tyle sens, o ile otwiera się na swoje „coś więcej” - na swoją transcendencję. 
Kardynał Wojtyła proponuje iść do osoby poprzez czyn; w czynie jej szuka. Czyn więc przedstawia się dla niego dwupłaszczyznowo; tak jak słowo-symbol, bezpośrednio i wprost mówi o sobie samym i równocześnie pokazuje czy też uobecnia w sobie swego sprawcę - osobę. Do niej trzeba nam dopiero dochodzić. Można nawet powiedzieć, że czyn jest symbolem naturalnym, to znaczy - w swoim poznawczo-uobecniającym momencie jest $\mathrm{w}$ pełni niezależny od poznającego podmiotu. W czynie znajduje się osoba, w nim się bowiem spełnia. „Czyn jest źródłem poznania osoby” (s. 31) a nieco dalej czytamy: „Studium niniejsze pomyślane jest właśnie jako takie stopniowe wydobycie czyli eksplikacja czynu pod kątem odsłaniania rzeczywistości osoby" (s. 32-33). Osobę ogląda się poprzez czyn (s. 17).

Nie ma symbolu bez hermeneutyki i odwrotnie: nie ma hermeneutyki bez symbolu. Symbol zawsze domaga się hermeneutyki, czyli interpretacji siebie, i zawsze tam, gdzie pojawia się hermeneutyka, mamy do czynienia $z$ symbolem. Jeżeli chodzi o metodę, według jakiej dokonuje się interpretacji, narzuca ją sam symbol. Zatem szukając w czynie zasymbolizowanej (obecnej w nim) osoby, należy jej szukać według reguł wyznaczanych przez sam czyn pojęty dwupłaszczyznowo. Czyn bierze się wówczas za ,tekst" domagający się interpretacji dokonywanej na wyznaczonej przez niego drodze ${ }^{2}$.

Czyn ,daje do myślenia”, żeby posłużyć się utartą już Ricoeurowskác zbitką językową a kryjącą w sobie wielkie przemyślenia, jakich dokonano w ostatnich latach. „Domyślać” dane do myślenia należy według symbolu.

Kardynał Wojtyła ukazuje przede wszystkim formalne struktury czynu, ich natomiast zawartość mniej go interesuje. Są to struktury, w jakich spełnia się ludzka osoba, dlatego praca ta wytycza hermeneutyczne drogi dla hermeneutyki osobowej zawartości czynu. Patrząc z tej strony na dzieło Kardynała Wojtyły nazwałbym je formalną hermeneutyką czynu, w ramach której winno się dochodzić do filozoficznej eksplikacji czynu uobecniającego osobę. Eksplikacji tej nigdy nie będzie można zakończyć, ponieważ nie pozwoli na to bogactwo uobecnionej w nim konkretnej osoby. Wolno, wydaje się, powiedzieć, iż studium Kardynała Wojtyły umożliwia spojrzenie na ludzki czyn jako na symbol oraz pokazuje zarazem, po jakiej drodze należy dokonywać jego hermeneutyki. Znając bowiem struktury czynu możemy dostrzec „struktury” samej osoby - Autor pamięta o starym adagium: agere sequitur esse.

2 Nie można zatem oceniać pracy Karynała Wojtyły - od strony metodologicznej - przykładając do niej wzorce wzięte skądinąd. Studium to posiada własną metodologię. Co najwyżej wolno je oceniać wychodząc z tych założeń, z których ono wychodzi, oraz biorąc pod uwagę ten przedmiot refleksji, jakim ono się zajmuje. 
Redukcyjny zabieg poznawczy, w znaczeniu, jakie nadaje temu słowu Autor - tak bardzo przypominający poznawczą drogę do absolutnej Osoby zasymbolizowanej w stwórczo-zbawczym czynie - zwraca uwage na zawarty w czynie i konstytuujący go właśnie w czyn moment sprawczości, z którym wiąże się moralność, czyli stawanie się człowieka samym sobą (dobro), ewentualnie niszczenie się (zło). Autokreacja oraz autodestrukcja, rozgrywające się w czynie, pozwalają najgłębiej, wydaje się, pojąc ludzką osobę, która w pewnej mierze już istniejąc jako ta speł-niona w stopniu nieskończonym znajduje się jeszcze nieskończenie daleko od swojego spełnienia. Pełna osoba mieści się daleko od teraźniejszego podmiotu, chociaż jakoś w nim jest uobecniona dzięki temu, że coś z niej już się spełniło w konkretnym czynie. Poprzez częściowe spełnienie uobecnia się całość - dlatego czyn ludzki jest symbolem całości; gdyby nie było w nim żadnego spełnienia osoby, tym samym przestałby być symbolem. Nieuchronnie więc hermeneutyka ludzkiego czynu kończy się chrystologią - znamienne, że ostatnie cztery strony rozważań Księdza Kardynała kończą się refleksją na temat znaczenia przykazania mi-łości, koło którego owija się właśnie chrystologia.

Wydaje mi się, że tak ujmując problem człowieka Autor od razu uzyskuje perspektywę, w której widać człowieka w jemu tylko właściwych ontycznych strukturach. Przy czym tworząc sobie w refleksji przedmiot filozofii człowieka, tzw. jedność znaczeniową dostrzeganą w wielości, ,takożsamych czynów", może pozwolić sobie na uogólnienia stanowiące wiedzę o człowieku (chętnie mówiłbym tu o ontologii człowieka). Z drugiej zaś strony wsparłszy refleksję na podmiocie działania podkreśla, że równocześnie jest to także (i to per prius) podmiot istnienia, czyli suppositum. Jako taki, mówi Autor (s. 47), człowiek dany nam jest w ,całościowym doświadczeniu”. Tym sposobem Autor nie odcina się od metafizyki bytu ludzkiego, od jego konkretności; w zgodzie z metafizyka bytu w ogóle ukazuje podstawy pod metafizykę człowieka — metafizykę ontycznych struktur antropologicznych. Wydaje się, że Autor wtedy, kiedy mówi o świadomości w końcowym obrachunku mówi raczej o existo aniżeli o cogito - w tym drugim dopatruje się s posobu istnienia człowieka. Kto wie, czy nie jest możliwe, jak zresztą sądzi Kardynał Wojtyła, przezwyciężenie tego, co nazywa rozszczepieniem tradycji filozoficznej, w jakiej żyjemy, na filozofię bytu oraz na filozofię świadomości. Naturalną koleją rzeczy należałoby szukać owego przezwyciężenia w odpowiedniej koncepcji człowieka, skoro pojawiło się ono właśnie $z$ powodu refleksji nad nim i w nim odbija się konfliktowym echem. 
Niedosyt czuję przy tych partiach książki, które mówią o tzw. stabilizacji przedmiotów doświadczalnych. W jeden przedmiot stabilizuje je umysł łącząc doświadczenie ludzkiej „,wewnętrzności” i ,zewnętrzności” w jedno. W doświadczeniu tym znajduje się także miejsce dla doświadczenia cudzej ,zewnętrzności” oraz cudzej ,wewnętrzności”. Całość tego doświadczenia Kardynał nazywa doświadczeniem człowieka. Konstytuuje je zarówno doświadczenie w ścisłym tego słowa znaczeniu jak i zrozumienie. Dzięki temu uzyskujemy tu, mówi Autor, możliwość budowania wiedzy o człowieku, którą ludzie komunikują sobie nawzajem, a którą rozumieją dlatego, że odnajdują jej desygnat w doświadczeniu siebie samych. ,Taka interferencja doświadczeń, będąca następstwem «gatunkowej» stabilizacji przedmiotu, stanowi z kolei podstawę dla kształtowania wiedzy o człowieku na podstawie zarówno tego, czego dostarcza doświadczenie człowieka, który jest mną, jak też doświadczenie każdego innego człowieka, który mną nie jest"' (s. 9).

Jeżeli dobrze rozumiem w tym miejscu wywód Autora, to w zasadzie rozróżnia on dwa doświadczenia - doświadczenie siebie oraz doświadczenie drugiego człowieka. Dostrzega ich niewspółmierność, ale równocześnie dostrzega ich takożsamość pozwalającą na uogólnienia. Otóż sądzę, że należałoby tutaj wyróżnić i przeanalizować cztery rodzaje doświadczenia: mianowicie doświadczenie swojej podmiotowości, czyli własnego wnętrza, doświadczenie własnej zewnętrzności (doświadczenie ciała), doświadczenie cudzej zewnętrzności oraz w szczególnych przypadkach doświadczenie cudzego wnętrza. Rzecz jasna doświadczenia własnej podmiotowości czy raczej własnego wnętrza nie da się z niczym porównać. Cudze wnętrze otwiera nam w pewnej mierze tak zwane "wczucie się". Bywają także niewątpliwie chwile, w których cudza ,wewnętrzność" promieniuje poprzez ,zewnętrzność”, w którą niejako jest spowita i którą swoim promieniowaniem niejako odrzeczowia. Nigdy jednak nie zniknie zasadnicza różnica pomiędzy rzeczywistością doświadczenia, w którym jego podmiot utożsamia się z ,przedmiotem”, a rzeczywistością tego doświadczenia, w którym tej tożsamości nie ma.

Doświadczenie mojej „zewnętrzności” także różni się i to zasadniczo od doświadczenia cudzej, ,zewnętrzności”. Moja, dana mi jest w organicznej całości, jaką tworzy razem z moją ,,wewnętrznością", podczas gdy cudza najczęściej nie. Ta ostatnia jedynie w rzadkich chwilach tworzy jakąś całość z promieniującą przez nią cudzą ,wewnętrznością”. Jest to jednak całość jawiąca mi się w kształcie przedmiotowym.

Doświadczenie stanów miłości, w których dochodzi do odnalezienia drugiego człowieka w sobie samym - doświadczenie mistyczne - wy-kracza, wydaje mi się, poza ramy rozważań Autora. Nie jest też bardzo jasne, co Autor rozumie przez ,określony kontakt”, na podstawie któ- 
rego ,wiedza" o cudzym wnętrzu przechodzi w ,,pewnego rodzaju doświadczenie cudzego wnętrza" (s. 10). Możliwe, że ma tu na myśli wspomniane wyżej przeze mnie „wczucie się" czy doświadczenie jakiegoś promieniowania, ale być też może, że co innego. Wiedza bowiem, jakiej drugi udziela mi o swoim wnętrzu, może zostać zweryfikowana w moim doświadczeniu własnego wnętrza, ale to jeszcze przecież nie jest doświadczenie cudzego wnętrza. Natomiast „wczucie się” czy „promieniowanie” może się pojawić bez uprzedniej wiedzy - owszem, samo staje się wiedzotwórcze. Jeżeli wiedza o drugim przekształca się w doświadczenie cudzego wnętrza, to przekształca się tak nie na skutek swoich immanentnych możliwości, ale na skutek zewnętrznych względem niej czynników.

Autor rozróżnia, jak powiedziałem, dwa doświadczenia: doświadczenie siebie oraz doświadczenie drugiego, stabilizując je w jeden przedmiot wiedzy o człowieku, powstały na gruncie jedności znaczeniowej relacji „człowiek działa” (s. 18). Stabilizacji tej dokonuje się, twierdzi Autor, na drodze arystotelesowskiej indukcji, to znaczy intelektualnego wglądu w konkret, uogólniającego to, co zostało dostrzeżone. Tu, wydaje się, tkwi trudność. Uogólnienie indukcyjne (heureza pojęć) opiera się na wglądzie w jeden albo więcej takich samych przedmiotów, ale danych mi $\mathrm{w}$ doświadczeniu jednorodnym, umożliwiającym utworzenie pojęcia. Jeżeli doświadczenia nie będą jednorodne (a za takie uważam doświadczenia siebie oraz drugiego), to sądzę, nawet wtedy, kiedy przedmiot ich będzie taki sam, wyniki poznawcze (otrzymane pojęcia, dające podstawę dla wiedzy) będą się różniły. Odkryją bowiem różne aspekty w doświadczanym przedmiocie. Owszem, w doświadczeniach tych może dojść do powiększenia naszej wiedzy, przez uzupełnienie jednego doświadczenia drugim - ale otrzymany przedmiot (ustabilizowany "gatunkowo") może zawierać momenty przekraczające to, co dane jest w poszczególnych doświadczeniach, wziętych osobno: w doświadczeniu siebie albo w doświadczeniu drugiego człowieka. Jeżeli się twierdzi, że jest inaczej, to należy pokazać, na jakiej podstawie (dzięki jakiej teorii? dzięki jakim założeniom?) przyjmuje się takożsamość d a n y ch w tych dwu doświadczeniach.

$\mathrm{Na}$ czym bowiem polega istotna różnica między doświadczeniem siebie a doświadczeniem drugiego człowieka? Wydaje się, że należy jej szukać przede wszystkim w tym, że doświadczenie siebie jest zarazem moim istnieniem, albo inaczej - sposobem istnienia tego, co filozofia tradycyjna nazywa suppositum. Tym, co przeżywam, czego doświadczam, jestem ja. Samo doświadczenie niejako powiększa mój byt; przemienia go. Gabriel Marcel mówi, że doświadczenie ,wciela się w nasz byt" 3 . Wolno więc powiedzieć, że doświadczenie siebie stanowi zarazem speł-

3 Gabriel Marcel, Journal Métaphysique, Paris 1935. 
nienie swojego świadomego bytu, którym jestem i który przeżywam. $\mathrm{W}$ doświadczeniu tym dane mi jest nie jakieś zjawisko mojego bytu, ale on sam wraz ze swoim sposobem bytowania.

Nie tak dany mi jest drugi człowiek. Nie jestem z nim tożsamy, nawet wtedy, kiedy „wczuwam się” weń. Moje doświadczenie jego rzeczywistości zawsze pozostaje na zewnątrz tego, czego jest doświadczeniem. Jeżeli ono zmienia mój byt, to tylko dlatego, że równocześnie jest doświadczeniem mnie samego. Doświadczenie drugiego człowieka przybiera kształt obiektywizacji drugiego podmiotu, natomiast doświadczenie siebie rozgrywa się jako przeżycie nie układające się w parę podmiot-przedmiot. Wy jątkowo doświadczenie drugiego, powiedziałbym ,zawiesza" ów dualizm w stanach, które najogólniej można nazwać miłością. Ale tylko „zawiesza” — robiąc miejsce dla przeżycia rzeczywistości „my”.

Arystotelesowska indukcja - w wyżej wspomnianym znaczeniu dokonuje abstrakcji $\mathrm{z}$ danych $\mathrm{w}$ tych doświadczeniach i tworzy gatunkowe pojęcia. Operacja ta jest dziełem intelektu, a ten działa w każdym $\mathrm{z}$ tych doświadczeń $\mathrm{w}$ obrębie możliwości przez nie wyznaczonych. I tu widzę trudności tego, co Kardynał Wojtyła nazywa stabilizacją przedmiotu. Inaczej bowiem kształtują się możliwości dla indukcji tam, gdzie podmiot ma do czynienia z przedmiotem, ewentualnie gdzie skazany jest na obiektywizację, a inaczej tam, gdzie przeżywa siebie. Oczywiście Autor może powiedzieć, że przedmiotem, w którym szuka osoby, jest czyn, a zatem coś już zobiektywizowanego (s. 19-20), niemniej wydaje się, że związek między podmiotem a czynem inaczej jawi się w doświadczeniu siebie a inaczej $\mathrm{w}$ doświadczeniu drugiego. W drugim przypadku dany jest $\mathrm{w}$ formie zobiektywizowanej, w pierwszym - nie.

Autor mówi wprawdzie o intersubiektywizacji przedmiotu, jakim jest osoba i jej czyn, określenie domaga się jednak doładniejszej eksplikacji. Bo na pierwszy rzut oka sugeruje ono po prostu to, że filozof analizuje własne doświadczenie siebie, czyli — w tym przypadku - związek własnego podmiotu z czynem, i że na drodze abstrakcji tworzącej pojęcia formułuje z tego doświadczenia przedmiot refleksji. Intersubiektywizacja następuje wówczas, kiedy drugi podmiot w przedmiocie tym (albo raczej: z jego okazji) odnajduje własne doświadczenie siebie. Być może, że on z kolei odkryje w tym swoim doświadczeniu coś nowego a co zakomunikowane otworzy pierwszemu nowe możliwości doświadczenia siebie. Moje doświadczenie drugiego nie odsłoni związków, jakie odkrywam między moją osobą a moim czynem: drugi jednak może mi potwierdzić, że to, co ja odkrywam w sobie, także i on dostrzega we własnym doświadczeniu siebie.

Ale czy o takim „,scaleniu” doświadczeń myśli Autor? Kiedy mówi, że takożsamość relacji osoba-czyn, konstytuująca doświadczenie siebie 
każdego podmiotu, to nic innego jak tylko ,,jedność znaczeniowa” (s. 18), będąca ,dziełem indukcji”, zdaje się potwierdzać taką interpretację. Do scalenia zatem doświadczeń (siebie oraz drugiego) dochodziłoby niejako w społecznym pojęciu rozumianym jako pewien wytwór zweryfikowany co najmniej przez dwa podmioty. Wtedy też — na płaszczyźnie pojęcia - doświadczenie drugiego, kształtujące się zazwyczaj przedmiotowo, może zostać wintegrowane w ową ,jedność znaczeniową”. Taka jednak interpretacja stabilizacji przedmiotu niesie ze sobą trudności. Czym bowiem wtedy jest przedmiot refleksji filozoficznej: rzeczywistością daną w doświadczeniu czy raczej pojęciową abstrakcją dokonaną na jej temat w ramach jảkiegoś systemu, być może nie uświadomionego sobie przez dokonujące ją podmioty. W drugim przypadku pojawia się problem stosunku opisu danych w doświadczeniach do jakiejś ich (danych oraz doświadczeń) prekoncepcji wpływającej na opis. Jeżeli chodzi o Osobę $i$ czyn, będzie to problem stosunku opisu fenomenologicznego do tradycyjnej metafizyki, na której gruncie Autor pozostaje i w ramach której wydaje się dokonywać, ,stabilizacji przedmiotu”.

Mówiąc o książce Kardynała Wojtyły trzeba zwrócić uwagę na model świadomości, jaki nam proponuje. Autor widzi w niej aspekt bytu domagający się eksplikacji. W filozofii tradycyjnej aspekt ów ,implikowała" racjonalność (animal rationale), a w etyce - wolność czynu.

Otóż według Autora Osoby i czynu świadomość, chociaż posiada charakter intelektualny (poznawczy) — jest bowiem rozumieniem — to jednak nie posiada struktury intencjonalnej. ,, Do niej należy tylko odbijanie" (s. 37). Takie stwierdzenie wychodzi poza tradycję filozofii fenomenologicznej, w której świadomość wiąże się nierozerwalnie z intencjonalnością. W filozofii współczesnej, posługującej się fenomenologią, tylko przeżycie siebie zintencjonalizowanego do przedmiotu nie posiada struktury intencjonalnej. Przeżycie przenika każdy intencjonalny akt świadomości, otwierając podmiotowość dla poznania.

Kardynał Wojtyła inaczej widzi problem. Według niego świadomość spełnia dwie funkcje - obydwie w sposób nieintencjonalny: o d z w i e rciedla oraz przeży wa. W skrócie ustawienie problemu wyglądałoby następująco: człowiek wchodzi poznawczo (intelektem) w otaczający go świat przedmiotów, istniejących niézależnie od niego jako podmiotu poznającego. Poznanie, właściwe temu skierowaniu, dokonuje się w strukturze intencjonalnej, łączy się z obiektywizacją poznawanego. Jego owocem jest wi ed z a.

Kiedy w ten sam sposób - tzn. intencjonalny - człowiek intelek-tualnie skierowuje się w stronę własnego ,ja’, mamy do czynienia z s a m ow i edzą. Samowiedza różni się od wiedzy tym, że jej przedmiot nie posiada charakteru ogólności, gdy tymczasem przedmiot wiedzy 


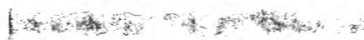

go ma. Przedmiot samowiedzy to konkretne, jednostkowe ,ja”. Samowiedza uprzedmiotowia poznawczo osobę oraz jej czyn, uprzedmiotowia „ja” związane sprawczym stosunkiem ze swoim czynem. Uprzedmiotowia także świadomość ze wszystkim, co ona zawiera odzwierciedlając i przeżywając.

Wiedza oraz samowiedza, jeżeli dobrze rozumiem Autora, dostarczają świadomości materiał już poznany i zrozumiany. Funkcja poznawcza (intelektualna) świadomości polega na rozumieniu już zrozumianego.

Rozumienie świadomości nie kształtuje się w strukturze, jak zaznaczyliśmy, intencjonalnej. Konsekwentnie nie ma $w$ świadomości rozbicia na podmiot-przedmiot. Przedmiot istnieje $w$ niej poprzez swój „obraz" - w ten sposób świadomość go odzwierciedla. Świadomość nie kształtuje go ani nie obiektywizuje poznawczo. Także i to, co daje jej samowiedza, świadomość odzwierciedla, równocześnie interioryzując. Interioryzacja, dokonująca się w przeżyciu, daje odzwierciedlanemu ,ja" miejsce we własnym, ja" świadomościowym (s. 38). Tak świadomość odzwierciedla w sobie osobę oraz jej czyn nie obiektywizując ani osoby, ani czynu. Ale to jeszcze nie utożsamia się ze ,świadomym działaniem"; to ostatnie jawi się wówczas, kiedy samowiedza obiektywizuje poznawczo samą świadomość. Wtedy człowiek działając ,wie”, że działa i że działa świadomie (por. s. 40).

Suma aktów odzwierciedlających tworzy stan świadomości, w jakim znajduje się człowiek będący jej podmiotem.

Samowiedza - mówi Autor (s. 40) — jest ,n i e ja k o w c z eśn i e jsza od świadomości", daje bowiem znaczeniową podstawę dla zawartości świadomości nie pozwalając jej tym samym oderwać się od bytu (s. 41). To samo da się powiedzieć i o wiedzy, bo przecież ona także dostarcza świadomości materiału do odzwierciedlenia. Samowiedza jednak zdaje się mieć jeszcze jedną funkcję - już po odzwierciedleniu i przeżyciu interioryzującym osobę wraz z jej czynem we własne ,,ja” dokonanych przez świadomość; samowiedza zwraca się w stronę świadomości oraz wszystkiego, co w niej odzwierciedlone i przeżyte. Tworzy wiedzę o zinterioryzowanym i niepowtarzalnym świecie osoby, nie naruszającą jednak w niczym jego zinterioryzowania. Nie następuje uprzedmiotowienie podmiotu, czego tak bardzo boją się egzystencjaliści. Alternatywa: wiedza albo wolność zostałaby zatem przezwyciężona $\mathrm{z}$ pomocą samowiedzy. Osoba dzięki samowiedzy posiadałaby charakter przedmiotowy, dzięki świadomości natomiast — podmiotowy. Jest, jak się wyraża Autor, podmiotowością przedmiotu.

Mielibyśmy więc trzy rodzaje aktów: akty wiedzy, samowiedzy oraz akty świadomości. Dwa pierwsze mają intencjonalną strukturę poznawczą, trzeci - nie. Poznawcza funkcja aktów świadomości sprowadza się 
do nieintencjonalnego odzwierciedlania oraz do refleksywnego przeżywania wiążącego ontologiczne suppositum ze świadomościowym ,ja" podmiotu. Jest to sposób bytowania „do wewnątrz” (s. 48), sposób urzeczywistniania swojego bytu.

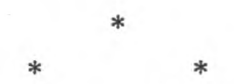

Kolej na pytania. Pierwsze pytanie dotyczy nowej koncepcji świadomości, nie funkcjonującej na sposób intencji. Jak jest możliwe pomyśleć świadome odzwierciedlanie bez zintencjonalizowania? Przecież odzwierciedlone nie utożsamia się $\mathrm{z}$ odzwierciedlającym. A jeżeli tak, to w jakich innych kategoriach można je pojąć, jak nie w kategoriach ,,podmiot-przedmiot"?

Drugie pytanie dotyka stosunku samowiedzy oraz wiedzy do świadomości. Swiadomość pozostaje w stosunku do ontologicznego „,ja" (do suppositum oraz do jego działania) za pośrednictwem tego, co na temat tego ,ja" mówi samowiedza. Skoro tak, to już uprzednio względem świadomości musiało nastąpić zrozumienie ,,ja" w jego sprawczym związ$\mathrm{ku} \mathrm{z}$ danym czynem. Podobnie $\mathrm{z}$ danymi wiedzy. Odzwierciedlenie zatem świadomości sprowadzałoby się jedynie do „magazynowania” treści samowiedzy oraz wiedzy. W odpowiednim momencie intelekt dokonywałby na nich operacji spekulatywnych już bez bezpośredniego odnoszenia się do odpowiednich konkretnych przedmiotów. Czy w ten sposób nie wróciliśmy do teorii rozumu biernego z jego species impressa oraz expressa? Przynajmniej w pewnym stopniu?

Świadomość nie tylko odzwierciedla ,ja” w relacji do własnych czynów, ale także, jak już zaznaczyliśmy, prze żywa tę relację, dzięki czemu czyny odbieramy jako nas z e czyny. I to chyba stanowi główną funkcję świadomości w zaproponowanym nam ujęciu tej ostatniej. Wydaje się jednak, że kiedy tak rozdzielimy poznanie, odzwierciedlanie i przeżycie, narażamy się na pewną grę in infinitum. Samowiedza bowiem obiektywizuje poznawczo to, co odzwierciedliła i przeżyła świadomość, a co sama uprzednio podała świadomości. Z kolei świadomość na nowo odbija i przeżywa to, co zobiektywizowała samowiedza. Następnie włącza się znowu samowiedza i tak dalej. Dzieje się mniej więcej tak, jak byśmy ustawili naprzeciw siebie dwa lustra. Aby uniknąć tego efektu, kto wie, czy nie będzie jednak potrzeba przypisać świadomości zdolności także do aktów intencjonalnych. Wówczas samowiedza byłaby pochodną samoświadomości, a świadomość nie tylko odbijałaby biernie, lecz także konstytuowałaby sensy przedmiotów - co niekoniecznie oznacza ich stwarzanie. 
$\mathrm{Na}$ koniec chciałbym dotknąć jeszcze jednego problemu, posiadającego ogromną doniosłość w dziedzinie etycznej: myślę o problemie natury. W swoim studium Kardynał Wojtyła najpierw oddziela ją od osoby, a potem pokazuje, jak dochodzi do integracji tejże natury przez osobę. Wydaje się, że w konsekwencji otrzymujemy dwa pojęcia natury: jedno abstrakcyjne, a drugie metafizyczne.

Do pierwszego pojęcia Autor dochodzi poprzez rozróżnienie pomiędzy czynem a uczynnieniem, wiążąc je z tym drugim. Otrzymuje je na drodze abstrakcji - naturę więc pojmuje się tu in abstracto (s. 80), tzn. jako coś wyabstrahowanego z konkretnych ludzi a ściślej mówiąc z ich uczynnień, bardzo zbliżonego do scholastycznej essentia speciei. Tę naturę się $\mathrm{ma}$, nią się nie jest. Jej pojęcie wskazuje, ,n a to, c o c złowiekowi jako człowiekowi jest właściwe” (s. 80). To „właściwe człowiekowi" Autor bliżej precyzuje posługując się pojęciami czynu oraz uczynnienia. Naturę więc odnajdujemy nie tam, gdzie mamy czyn (gdzie „człowiek działa” sprawczo), lecz tam, gdzie „coś dzieje się w człowieku" (s. 81). Naturę konstytuuje dynamizm podmiotu z góry mu dany, przygotowany, ,poniekąd bez reszty w jego podmiotowej strukturze dynamicznej" (s. 81).

Wyraźnie zostały rozgraniczone dwa światy: świat osoby oraz świat natury, niemniej nie jest wyraźnie powiedziane „do końca”, co należy konkretnie rozumieć pod pojęciem uczynnienia, jakie treści należy w nie włożyć. Można bowiem widzieć w nim równie dobrze Tomaszowy dynamizm do dobra (syntereza, która $\mathrm{m}$. inn. wyraża się $\mathrm{w}$ inklinacji do szukania prawdy), przeradzający się $\mathrm{w}$ dynamizm ku wartościom, jak i dynamizm czysto biologiczny. Nie jest też jasne, jak należy rozumieć stwierdzenie, że sfera uczynnień (Ricoeurowskie l'involontaire) wskazuje na istotę ludzką, przez którą człowiek jest człowiekiem (s. 80). $\mathrm{Na}$ co wtedy wskazywałoby le volontaire? Przecież ono nadaje sens temu, co jest involontaire w człowieku, a nie odwrotnie. Człowieka zaczynamy pojmować raczej w perspektywie ,ja chcę” aniżeli — „coś się we mnie dzieje”, „coś się we mnie domaga czegoś” itp. To drugie może służyć za motyw, za ograniczenie itd., zrozumiałe jednak staje się dopiero w świetle pierwszego. Powiedziałbym, że ,uczynnienie” staje się zrozumiałe dopiero w świetle ,czynu” — bez niego jest nie-ludzkie.

W konsekwencji trudno będzie potem przewyciężyć zabieg oddzielający świat osoby od świata natury (pozwalający widzieć w osobie sprawcę czynów, a w naturze - „sprawcę" uczynnień) integracją dokonującą się w suppositum. Natura bowiem rozumiana jako essentia speciei, wyabstrahowana od ludzkiej całości, znajduje się na innej płaszczyźnie aniżeli osoba, którą się jest. Pierwsza znajduje się na płaszczyźnie pojęciowej, druga - bytowej. Odpowiednik natury-pojęcia mieszczący się 
w suppositum jest inny, ponieważ przenika go osoba, stanowiąca o istocie człowieka, o jego dynamizmie. Warto w tym miejscu zastanowic się, czy opis fenomenologiczny doświadczenia siebie jako człowieka swojej całości ukonstytuowanej przez ,,wewnętrzność” oraz przez ,,zewnętrzność" - uprawomocnia dokonywanie tego rodzaju abstrakcji.

Z drugiej jednak strony takie rozgraniczenie, jakiego dokonał Kardynał Wojtyła, znakomicie tłumaczy, na czym polega uwarunkowanie ludzkiej wolności; pokazuje nie to, że jest ona wolnością jeszcze nie zrealizowaną (niepełną), lecz to, w jakich warunkach musi i może się realizować. Tylko znowu: warunki te wzięte w swojej abstrakcyjnej prawdzie nie ukazują bytowej, konkretnej prawdy uwarunkowań ludzkiej wolności. Jak widać, daje tu znać o sobie dylemat: prawda pojęć czy prawda konkretu? Jakie rysuje się wyjście $z$ tej kłopotliwej sytuacji, to juz osobny problem. 